\title{
Russian science bodies still at loggerheads
}

Moscow. The Russian Academy of Sciences has backed suggestions from a group of experts from the Organization of Economic Cooperation and Development (OECD) that there should be a pruning of the scientific community and a weeding out of less effective scientific institutions.

The academy's recommendation is one of a number of suggestions presented to Russian President Boris Yeltsin in response to his request for proposals from both the academy and the Ministry of Science on improving the organization of Russian science (see Nature 365, 283; 1993).

The two institutions presented their replies at the end of last month. Some of their

recommendations are similar. For example, both strongly criticize the way in which funding for scientists is now distributed, which the ministry in particular considers to be the main reason for the disappointment of scientists in the president's policies.

Both agencies also advise Yeltsin to stop financing ineffective scientific institutions. But the academy states its position much more strongly than the ministry. It says that a thorough review of scientific institutions is necessary, after which "ineffective research groups should be closed down".

The academy also recommends that control of all basic research in Russia should be placed under its leadership. Indeed, top acad-

\section{US 'should re-create national bioethics forum'}

Washington. The US Office of Technology Assessment (OTA) has proposed that Congress should re-establish a national forum for debating the ethical implications of biomedical research and medical practices. The OTA is not charged with making formal recommendations to Congress but says it favours the creation of a broad-based commission over a more ad hoc approach, which should be considered only as a "last resort".

The OTA's analysis is made in a report, Biomedical Ethics in US Public Policy, details of which were released last week at a hearing held by the Senate Labor and Human Resources Committee.

It has been four years since the last government-sponsored bioethics forum, the Biomedical Ethics Advisory Committee (BEAC), went out of business. It did so after congressional members of the Biomedical Ethics Board, set up to oversee BEAC, became deadlocked along partisan prochoice/anti-abortion lines.

Previous federal ethics bodies had some success in the 1970s and early 1980s. But however successful these bodies may have been, they did not end the need for further study, says Alexander M. Capron, of the University of Southern California Law Center, Los Angeles.

Those who support the notion of reestablishing a bioethics forum say that topics such as the conduct of AIDS vaccine trials, the compassionate uses of gene therapy, germline gene therapy, and the patenting of human tissues, cells or DNA are just a few of the areas that may raise unresolved ethical issues.

As part of its study, OTA has identified a number of factors that, irrespective of the type of body established, appeared to be crucial for the success of future efforts. Foremost among them, it says, is the need for adequate funding. OTA estimates that a standing body located within an existing government agency could cost about US $\$ 750,000$ a year to run. One that would operate as an independent commission for a set term could cost less than US $\$ 2$ million a year for four years.

The experience with BEAC has, not surprisingly, left many in Congress reluctant to reconsider the issue of bioethics. The last attempt "really left a bad taste in a lot of people's mouths" says a congressional aide to Senator Mark Hatfield (Republican, Oregon). Nevertheless Hatfield, one of three senators to request the OTA study, introduced a bill in May that would establish a 15-member ethics advisory board within the Department of Health and Human Services. Although Hatfield says that he is not wedded to the idea of a permanent ethics advisory board, he hopes that introducing his bill will serve to focus the debate within Congress.

Diane Gershon emy officials have been urging Yeltsin to sign a decree confirming its authority.

In addition, the academy would also like to be given responsibility for the budgets allocated to university research, leaving to the Ministry of Science the management of the state scientific and technical programmes.

In contrast, the ministry, headed by the Minister of Science, Boris Saltykov, has disagreed with the OECD's conclusion that Russia has too many scientists (and scientific institutions), apparently worried that drastically reducing their numbers could have serious social consequences (see Nature 365, 379; 1993).

In contrast to the academy, with which it remains in conflict, the ministry does not make any radically new proposals. Its main suggestion is that public spending on research should increase from three to four per cent of the state budget. And the ministry also repeats its suggestion for the creation of a system of "state professors".

Previously the ministry had suggested that 5,000 such posts be created; in the current proposal, this has been increased to between 10,000 and 15,000 . In order to carry out this programme, the ministry proposes to create a special Foundation of Basic Research to be given 5 per cent of the total scientific budget of Russia. But has ignored the idea of paying stipends of 75,000 rubles (about $\$ 70$ a month) to "outstanding scientists" which has been proposed by the academy and approved by Yeltsin.

The ministry has also given up the idea that academy institutes might be included in a system of federal scientific centres. It says that it plans to submit a proposal for another system of such centres - this time purely within the academy. Vladimir Pokrovsky

\section{Minister disbands German health bureau}

Munich. The German parliament is to decide whether to accept a proposal from UNAVAILABLE the health minister, Horst Seehofer, to disband the federal health bureau, which he says is not fulfilling its advisory function, and require the research institutes it runs to report directly to government ministries.

Seehofer recently dismissed the president and director of the bureau following a row over HIV-infected blood (see Nature 365, 594; 1993). Now he says that these posts will not be filled, and that the bureau's 300-strong Berlin-based central administration, which controls more than 3,000 staff in six major institutes and several working groups, should be dismissed

In the shake-up Seehofer is proposing, six institutes would become directly answerable to the health minister, and one be transferred to the environment ministry. As well as conducting research, each of these institutes helps to set and control standards in different health areas.

Seehofer's row with the bureau earlier this month did not reveal any new statistics for the number of people contracting AIDS through contaminated blood or blood products. But wide press coverage renewed public alarm, with many patients electing to cancel routine operations.

In response Seehofer says he intends to set up a DM10 million (US\$4 million) fund to help victims. He has also promised an independent inquiry into all incidences of AIDS infection from blood sources, to be completed by Christmas.

Alison Abbott 